\title{
An Empirical Test \\ of the View of Inventory as a Liability in Explaining Financial Distress
}

Benjamin P. Foster, (bpfosto1@ulkyvm.louisville.edu), University of Louisville M. Cathy Sullivan, (sullivmc@jmu.edu), James Madison University

Terry J. Ward , (tward@mtsu.edu), Middle Tennessee State University

\begin{abstract}
This study reports a first attempt in a financial distress context to test the extreme JIT and TOC view that inventory is a liability. We compared inventory levels and the change in inventory for healthy and financially distressed manufacturing firms. We also compared the explanatory power of logistic regression models including traditional accounting ratios to that of models including accounting ratios created by viewing inventory as a liability. We found some support for the extreme view of some JIT and TOC proponents that traditional inventory should be considered a liability.
\end{abstract}

\section{Introduction}

I $\mathrm{n}$ the Statement of Financial Accounting Concept No. 2 (FASB 1980, 22), the Financial Accounting Standards Board (FASB) adopted the decision usefulness criterion. Under this criterion accounting standard setters should focus on requiring information that is useful to users of financial statements. New management philosophies and their associated financial performance measures warrant that the FASB consider requiring additional information beneficial to financial statement users.

Just-in-time (JIT) inventory production and the theory of constraints (TOC) have become influential management philosophies. Propo-

Readers with comments or questions are encouraged to contact the authors via e-mail. nents of both JIT and TOC acclaim these concepts as the way to save American businesses and claim that managers must follow the concepts to stay competitive. Both JIT production and adoption of TOC concepts have been credited for the success of many companies. ${ }^{1}$

An underlying concept of both JIT and TOC is inventory reduction because carrying inventory is costly to a company. "Managers in ... companies that have implemented just-in-time systems, believe inventory is waste ..." (Horngren, et al. 1997, 722). In fact, characters in The Goal (Goldratt and Cox 1992, 272) engage in the following dialog: "Maybe I should start with a question," he says. "Do you agree that inventory is a liability?" "Of course, everybody knows that. And even if we didn't know it, 
the last few months have shown to what extent inventory is a liability." Goldratt also states that inventory is a liability in other writings (e.g. 1990, 25).

From a managerial and operational perspective, both JIT and TOC view inventory as a source of inefficiency and as detrimental to a company's financial performance. Goldratt is so unimpressed with traditional accounting measures that he has proposed his own measures of financial performance. (We discuss these measures more fully in a later section.) We would like to test the ability of Goldratt's measures to improve financial distress models. However, to accurately construct Goldratt's measures we would need to know the amount of raw materials, direct labor, and overhead included in each company's work-in-process and finished goods inventories. Consequently, we can only test the extreme JIT and TOC view of traditional accounting inventory as a liability.

\section{In Statement of Financial Accounting} Concepts No. 2, the FASB noted that the major users of financial accounting information were lenders and investors (FASB 1980, 22). Given the claims of JIT and TOC proponents, we want to address the question of whether or not treating inventory as a liability can improve the ability of accounting ratios to explain financial distress. Explaining firm financial health or distress appears to be an appropriate test construct because current literature provides many examples of turning around distressed firms with TOC concepts. (For example see Noreen et al. 1995, 107-125; Goldratt 1994; Goldratt and Cox 1992; and Institute of Management Accountants 1992). Improving financial distress models could be particularly useful to lenders and could also assist auditors in making the decision of whether or not to issue a going concern opinion. Consequently, this paper reports the results of an attempt to empirically test if viewing inventory as a liability can increase the explanatory power of financial distress models.

Results somewhat support the extreme assertion associated with JIT and TOC, that in- ventory is a liability. We believe results of our analysis provide some support for the notion that inventory should be considered a liability. This initial finding creates the desire for us to fully test the usefulness of Goldratt's financial performance measures. Our inability to obtain the information needed to construct those measures points out a weakness in current reporting standards; financial statement users cannot construct potentially useful measures due to the aggregation of inventory information in current financial reports. Consequently, our study also provides some basis for requesting that the Financial Accounting Standards Board require more detailed inventory reporting.

The rest of this paper is organized as follows: the second section discusses JIT and TOC, the third section discusses our research methods, the fourth section discusses our results, and the last section contains our conclusions.

\section{JIT and TOC}

Inventory reduction and small production batch size are key components of both JIT and TOC.

\section{JIT}

Benefits of adopting JIT, cited by proponents, include increased profitability, increased return on assets, and increased working capital. These advantages are either directly or indirectly a result of inventory reduction. Financial benefits provided by JIT include (Horngren, et. al 1997, 725): (1) Lower investment in inventory, (2) Reduced carrying and handling costs of inventories, (3) Reduced obsolete inventory, (4) Reduced setup and manufacturing costs, (5) Reduced waste and spoilage, (6) Lower investment in capital (i.e. plant space), and (7) Reduced accounting and paperwork.

TOC

Goldratt (the originator of TOC) proposes financial performance measures that differ from traditional accounting measures. Goldratt 
advocates Throughput Accounting, an accounting system built on what he calls throughput, operating expenses, and inventory. Unfortunately, Goldratt uses some of the same accounting terminology but applies different definitions to his measures. Throughput is revenues minus any variable costs not generated by the entity. Operating expense consists of all costs necessary to operate the company, including direct labor and overhead. Finally, his definition of inventory is the traditional definition of operating assets, everything the company owns that helps convert raw materials into throughput. Creating more confusion, Goldratt refers to traditional accounting inventory as 'inventory' in some of his writings. (The quote from The Goal in the first section of this paper is an example.)

With regard to traditional inventory, the only cost included in inventory under TOC is the cost of direct materials. Fundamental to TOC is the premise that all labor and all overhead adds value to the company, not the product. Therefore, the inventory value does not include the cost of direct manufacturing labor or manufacturing overhead.

TOC proponents and accounting researchers cite case study evidence supporting the benefits of using TOC concepts internally (for example, see Noreen et al. 1995, 61-135). Many of the cited examples of TOC success stories involve turning distressed firms nearing insolvency into profitable firms by introducing TOC concepts. One of the initial TOC writings, The Goal (Goldratt and Cox 1992) provides an example of this turn-around activity. Consequently, we wanted to test the ability of TOC performance measures to distinguish between healthy and distressed firms.

We attempted to construct the TOC measures of throughput and inventory from reported accounting information. However, calculating throughput and the TOC measure of inventory requires a separate reporting of each traditional inventory category and breaking down work-in-process and finished goods inventory by the components of raw materials, direct labor, variable overhead, and fixed overhead. Companies do not provide such a breakdown. Also, some companies combine different inventories into one total such as: (1) raw materials and work-in-process inventories, or (2) raw materials and supplies inventories.

Although we could not derive the TOC definition of inventory from financial statements prepared according to GAAP, we attempted to examine the appropriateness of the extreme view espoused by JIT and TOC proponents: that inventory is a liability. (Remember that although Goldratt defines inventory as something near to operating assets, he refers to traditional accounting inventory when he says inventory is a liability.) Goldratt $(1990,25)$ also emphasizes the disincentive to reduce inventory because of traditional financial accounting for inventory. This paper reports the results of the first empirical test that inventory (as reported in financial statements) is a liability.

\section{Research Methods}

Since Beaver's (1966) initial study, explaining financial distress has been used extensively in research as a criterion for evaluating the usefulness of accounting information. Consequently, we use well established methods to examine the usefulness of accounting information based on the JIT and TOC concept of inventory as a liability. We analyzed data from manufacturing firms because most cases that cite successful JIT or TOC applications are in the manufacturing area. (For example, see Noreen et al. 1995, 61-135.) Our study compared the explanatory power of logistic regression models to examine whether or not inventory should be considered a liability by manufacturing firms.

\section{Sample selection and statistical method}

From The Wall Street Journal Index (computerized database) and Compact Disk Disclosure we identified manufacturing companies that had defaulted on interest or principal payments, received a favorable debt accommodation, or filed for bankruptcy (distress events) in 
1992 or 1993 . We then randomly matched these companies with healthy companies from the same two digit SIC. Any companies without complete data on Compustat PC+ for the three years prior to the distress event were dropped from the sample.

We next examined each sample firm's annual report or $10-\mathrm{K}$ to verify the distress event for the distressed firms and the lack of a distress event for the healthy firms. We also dropped companies that had unaudited financial statements, that did not use U.S. GAAP, or whose management was under investigation for fraudulent financial statement reporting. We tried to find at least two healthy matches for each distressed firm. Our final sample contained 76 healthy and 32 distressed manufacturing firms for a total of 108 sample firms.

Preliminary analysis included using standard t-tests to test for a difference between the value of inventory held and the change in inventory for the healthy and distressed firms. We used binary logit regression to statistically test whether treating inventory as a liability could improve the ability of accounting information to distinguish between healthy and distressed manufacturing companies. Using logistic regression follows the research methods of many previous financial distress studies. (For example, see Lau 1987, Aziz et al. 1988, Aziz and Lawson 1989, Ward 1994, and Ward and Foster 1996.) ${ }^{2}$

\section{Response variable}

This study uses a dichotomous dependent response variable of healthy versus distressed firms. Firms were classified as distressed that had declared bankruptcy or experienced a loan principal/interest default or favorable debt accommodation (extension of cash payment schedules, reduction in principal, or reduced interest rates). The dependent variable in this study is coded as follows: FIRM $=0$ if firm had not experienced an distress event and FIRM $=1$ if firm filed, or was forced to file, for bankruptcy or if firm experienced a loan principal or interest default or favorable debt accommodation.

\section{Independent variables}

Because the focus of our analysis was limited to the impact of treating inventory as a liability in financial distress models, we began the analysis with a comparison of inventory variables between the healthy and distressed firms. We examined the inventory amount scaled by total assets:

INVTA $=$ inventory/total assets.

When using a multi-state response variable, Ward and Foster (1996) found that the change in inventory significantly helped to explain a firm's level of financial distress one year prior to the distress event. Consequently, we also examined the change in inventory scaled by total assets:

CINVTA = (ending inventory - beginning inventory)/total assets.

The view of inventory as a liability then led us to examine inventory scaled by all assets except inventory:

INVADJTA = inventory/(total assets- inventory)

and the change in inventory scaled by total assets less inventory:

CINVADJTA $=$ (ending inventory - beginning inventory) / (total assets-inventory).

The view of inventory as a liability also lead us to compare the results of current financial distress models with the results from distress models with independent variables that differed only by the treatment of inventories.

One model set includes traditional accounting ratios as independent variables while the other model set includes ratios adjusted to treat inventories as a liability as independent variables. Ward and Foster (1996) used a similar technique to evaluate the usefulness of depreciation and deferred tax allocations in explaining financial distress. Consequently, we used the same explanatory variables as Ward and Foster 
$(1996,144)^{3}$ :

SIZE $=\log$ of total assets,

SALESCA = sales divided by current assets,

CACL $=$ current assets divided by current liabilities,

OETL = owners' equity divided by total liabilities,

CATA $=$ current assets divided by total assets,

CASHTA $=$ (cash plus marketable securities) divided by total assets,

$\mathrm{CFFO}=$ cash flow from operating activities divided by total assets,

CFFI = cash flow from investing activities divided by total liabilities,

CFFF $=$ cash flow from financing activities divided by total liabilities,

NITA $=$ net income divided by total assets.

Ward and Foster (1996) chose the first six ratios because prior researchers found those variables important in financial distress models. (For example, see Casey and Bartczak 1984 and 1985; Gentry et al. 1987; Bahnson and Bartley 1992; and Ward 1993 and 1994.) Some of these previous studies also found that net income also significantly explained future financial distress. Neill et al. (1991), after completing a metaanalysis of cash flow studies, recommended including the three cash flow variables in future financial distress models. Ward (1993) examined the usefulness of cash flows in financial distress models and recommended the above scaling measures for cash flow variables.

In our second set of models, we adjusted the above variables to regard inventory as a liability. The model included the resulting ten independent variables:

SIZE $=\log$ of (total assets - inventory),

SALESCA = sales divided by (current assets inventory),

$\mathrm{CACL}=$ (current assets - inventory) divided by

(current liabilities + inventory),

OETL $=$ (owners' equity - inventory) divided by

(total liabilities + inventory),

CATA = (current assets - inventory) divided by (total assets - inventory),
CASHTA $=$ (cash plus marketable securities) divided by (total assets - inventory),

CFFO = cash flow from operating activities divided by (total assets - inventory),

CFFI $=$ cash flow from investing activities divided by (total liabilities + inventory),

CFFF $=$ cash flow from financing activities divided by (total liabilities + inventory),

NITA = net income divided by (total assets - inventory).

Freeman $(1987,237)$ noted that to obtain robust statistical results from logistic regression results, the sample must have at least $[(1+S) \times$ 10] observations, where $S$ equals the number of independent variables in the model. Consequently, our small sample size of 108 companies limited the number of independent variables we should include in our models. We first performed the logit analysis on the variables above, then deleted all variables that were not significant in any model for any year; SALESCA, CACL, and CASHTA were omitted from the rest the analysis.

Removing these variables from the models allowed us to obtain more valid statistical results and to add the change in inventory to the above models. Thus, for both the traditional and adjusted models we performed analysis with a reduced model that included SIZE, OETL, CATA, CFFO, CFFI, CFFF, and NITA. We also performed analysis with a full model that included those variables and CINVTA. We calculated the Change in -2Log Likelihood statistic from the reduced to full model to examine the significance of adding CINVTA to the models.

\section{Results}

Table 1 reports the results from a univariate comparison of inventories (INVTA and INVADJTA) and inventory change (CINVTA and CINVADJTA) between the two groups. Table 1 reveals that inventories may contain some useful information. The inventory variables were not significantly different between the two groups in any of the three years prior to the distress event. However, the change in inventory 


\begin{tabular}{|c|c|c|c|c|}
\hline \multicolumn{5}{|c|}{$\begin{array}{c}\text { Table } 1 \\
\text { Univariate Analysis } \\
\text { Comparison of Means }\end{array}$} \\
\hline Variable & Firm Code & Year-3 & $\underline{\text { Means }}$ & $\underline{\text { Year-1 }}$ \\
\hline \multirow[t]{2}{*}{ INVTA } & Healthy & 0.228 & 0.232 & 0.219 \\
\hline & Distressed & $\underline{0.234}$ & $\underline{0.242}$ & $\underline{0.24}$ \\
\hline Difference & & $-\overline{-0.006}$ & -0.01 & -0.021 \\
\hline \multirow[t]{2}{*}{ CINVTA } & Healthy & 0.011 & 0.022 & -0.005 \\
\hline & Distressed & $\underline{0.009}$ & -0.011 & -0.111 \\
\hline Difference & & 0.002 & $0.033^{*}$ & 0.106 \\
\hline \multirow[t]{2}{*}{ INVADJTA } & Healthy & 0.348 & 0.356 & 0.328 \\
\hline & Distressed & $\underline{0.349}$ & $\underline{0.37}$ & $\underline{0.372}$ \\
\hline Difference & & $-\overline{-0.001}$ & $-0 . \overline{014}$ & $-\overline{-0.044}$ \\
\hline \multirow[t]{2}{*}{ CINVADJTA } & Healthy & 0.02 & 0.036 & -0.007 \\
\hline & Distressed & $\underline{0.015}$ & $\underline{-0.018}$ & $\underline{-0.012}$ \\
\hline \multicolumn{2}{|l|}{ Difference } & 0.005 & $0.054^{*}$ & 0.005 \\
\hline \multicolumn{5}{|c|}{ *Significant difference at $p$-value $\leq .02$} \\
\hline \multicolumn{5}{|c|}{ 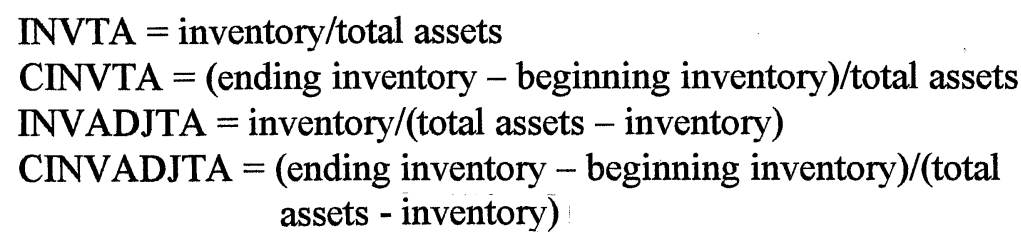 } \\
\hline
\end{tabular}

variables were significantly different two years before the event (with a $\mathrm{p}$-value of $<.02$ ). The statistics indicated that distressed firms decreased their inventories by a significantly greater amount than healthy firms two years prior to distress. Ward and Foster (1996) produced similar findings one year prior to a distress event for a sample including firms from several industries.

These results indicate that inventory may provide important information in financial distress models. The significant reduction in inventory could result from distressed firms selling off their inventories to raise needed cash. Perhaps a more likely explanation is that the inven- tory change may significantly explain future distress by indicating that weak firms had accumulated too much inventory. (Note that the average inventory value for the distressed firms is higher than that for the healthy firms.)

Next, we conducted logistic regression analysis to determine if adding a change in inventory variable (CINVTA) or viewing inventory as a liability could improve financial distress models. Table 2 reports the results from models that include traditional accounting ratios. Panel A reports results from reduced models that do not include CINVTA, while Panel B reports results from the full models. Table 2 includes the overall model -2 log likelihood statistics, parameter estimates for independent variables, and the $p$-values for Wald chisquare statistics related to those parameter estimates. We ran the models on financial data lagged one, two, and three years prior to the distress event.

Table 3 reports the same information as that reported in Table 2, but for models developed with ratios adjusted to treat inventory as a liability.

For each year of the analysis, results from the unadjusted and adjusted models vary considerably. Wald chi-square statistics indicate that different variables, and a different number of variables, are significant in the unadjusted and adjusted models. However, correlation among the parameter estimates requires caution in evaluating the Wald chi-square statistics produced by the models. Stone and Rasp (1991, p. 
TABLE 2

Logistic Regression Analysis with Unadjusted Models

\begin{tabular}{|c|c|c|c|c|c|c|}
\hline \multirow{2}{*}{ Variables } & \multicolumn{2}{|c|}{ Year -3} & \multicolumn{2}{|c|}{ Year -2} & \multicolumn{2}{|c|}{ Year - 1} \\
\hline & $\begin{array}{l}\text { Parameter } \\
\text { Estimates }\end{array}$ & P-Values $^{2}$ & $\begin{array}{l}\text { Parameter } \\
\text { Estimates }\end{array}$ & P-Values & $\begin{array}{l}\text { Parameter } \\
\text { Estimates }\end{array}$ & $\overline{\text { P-Values }}$ \\
\hline \multicolumn{7}{|c|}{ Panel A, Unadjusted Reduced Model ${ }^{1}$} \\
\hline Intercept & 1.460 & 0.234 & 1.872 & 0.158 & 5.382 & 0.010 \\
\hline SIZE & 0.178 & 0.221 & -0.266 & 0.107 & -0.493 & 0.036 \\
\hline OETL & -0.955 & 0.002 & -0.947 & 0.003 & -2.974 & 0.000 \\
\hline CATA & -1.226 & 0.352 & -1.043 & 0.449 & -3.356 & 0.084 \\
\hline CFFO & 0.9446 & 0.641 & 3.010 & 0.340 & -8.678 & 0.227 \\
\hline CFFI & 3.070 & 0.012 & 0.764 & 0.065 & 0.923 & 0.800 \\
\hline CFFF & 1.069 & 0.393 & 1.666 & 0.015 & 3.967 & 0.305 \\
\hline NITA & 0.579 & 0.739 & -0.910 & 0.475 & -3.614 & 0.273 \\
\hline Model -2 & $\mathrm{~L}^{3}$ & $18 * *$ & 21.0 & & 73.7 & *** \\
\hline \multicolumn{7}{|c|}{ Panel B, Unadjusted Full Model ${ }^{1}$} \\
\hline Intercept & 0.927 & .475 & 2.015 & 0.138 & 5.642 & 0.009 \\
\hline SIZE & -0.207 & .168 & -0.286 & 0.099 & -0.513 & 0.033 \\
\hline OETL & -1.080 & .001 & -0.941 & 0.003 & -2.978 & 0.000 \\
\hline CATA & -0.321 & .825 & -0.892 & 0.517 & -3.602 & 0.072 \\
\hline CFFO & 6.699 & .989 & 1.548 & 0.663 & -10.111 & 0.190 \\
\hline CFFI " & 3.822 & .004 & 0.752 & 0.073 & 0.908 & 0.804 \\
\hline CFFF & 1.560 & .171 & 1.493 & 0.022 & 3.619 & 0.358 \\
\hline NITA & -4.348 & .212 & -0.169 & 0.894 & -2.966 & 0.392 \\
\hline CINVTA & -6.797 & .099 & 8.672 & 0.070 & 3.771 & 0.606 \\
\hline \multicolumn{2}{|c|}{ Model -2 LOG L } & $23.716^{* *}$ & \multicolumn{2}{|c|}{$24.931^{* *}$} & \multicolumn{2}{|c|}{$74.019 * * * *$} \\
\hline \multicolumn{7}{|c|}{ Change in -2 LOG $\mathrm{L}^{4}$} \\
\hline
\end{tabular}

${ }^{1}$ The models included the following variables: SIZE $=\log$ of total assets, OETL $=$ owners' equity divided by total liabilities, CATA = current assets divided by total assets, CFFO = cash flow from operating activities divided by total assets, CFFI = cash flow from investing activities divided by total liabilities, $\mathrm{CFFF}=$ cash flow from financing activities divided by total liabilities, NITA $=$ net income divided by total assets, and CINVTA $=$ (ending inventory - beginning inventory/total assets.

The response variable for each firm, FIRM $=0$ if healthy, 1 if bankrupt or caused loss to creditors (76 healthy and 32 distressed manufacturing firms).

${ }^{2} \mathrm{P}$-value of the Wald chi-square statistic for each parameter estimate.

${ }^{3}$ The -2Log Likelihood Statistic follows a Chi-square distribution with seven degrees of freedom for the reduced model and eight degrees of freedom for the full model.

${ }^{4}$ The Change in -2Log Likelihood Statistic follows a Chi-square distribution with one degree of freedom.

$*$ Significant at $\mathrm{p}$-value $<.05$

$* * *$ Significant at $\mathrm{p}$-value $<.001$
$* *$ Significant at $\mathrm{p}$-value $<.01$

$* * * *$ Significant at $\mathrm{p}$-value $<.0001$ 


\begin{tabular}{|c|c|c|c|c|c|c|}
\hline \multicolumn{7}{|c|}{$\begin{array}{c}\text { TABLE 3 } \\
\text { Logistic Regression Analysis with Adjusted Models }\end{array}$} \\
\hline & \multicolumn{2}{|c|}{ Year -3} & \multicolumn{2}{|c|}{ Year -2} & \multicolumn{2}{|c|}{ Year - 1} \\
\hline Variables & $\begin{array}{l}\text { Parameter } \\
\text { Estimates }\end{array}$ & P-Values $^{2}$ & $\begin{array}{l}\text { Parameter } \\
\text { Estimates }\end{array}$ & P-Values & $\begin{array}{l}\text { Parameter } \\
\text { Estimates }\end{array}$ & $\overline{\text { P-Values }}$ \\
\hline \multicolumn{7}{|c|}{ Panel A, Adjusted Reduced Model $^{1}$} \\
\hline Intercept & 0.024 & 0.983 & 1.567 & 0.171 & 3.031 & 0.034 \\
\hline SIZE & -0.021 & 0.880 & -0.116 & 0.451 & -0.266 & 0.171 \\
\hline OETL & -2.581 & 0.001 & -2.490 & 0.000 & -3.979 & 0.000 \\
\hline CATA & -2.362 & 0.125 & -4.407 & 0.009 & -8.384 & 0.000 \\
\hline CFFO & 2.341 & 0.023 & 2.617 & 0.163 & -2.884 & 0.390 \\
\hline CFFI & 2.696 & 0.222 & 2.416 & 0.002 & -1.660 & 0.748 \\
\hline CFFF & 0.048 & 0.983 & 4.456 & 0.001 & 3.306 & 0.486 \\
\hline NITA & -1.084 & 0.031 & -1.685 & 0.155 & -5.171 & 0.015 \\
\hline Model -2 & $\mathrm{G} \mathrm{L}^{3}$ & $75 * * *$ & 29.8 & $* * *$ & 69.7 & \\
\hline \multicolumn{5}{|c|}{ Panel B, Adjusted Full Model ${ }^{1}$} & & \\
\hline Intercept & -0.149 & .902 & 2.308 & 0.067 & 3.057 & 0.035 \\
\hline SIZE & -0.025 & .862 & -0.194 & 0.253 & -0.268 & 0.169 \\
\hline OETL & -2.807 & .001 & -2.738 & 0.000 & -3.98 & 0.000 \\
\hline CATA & -2.144 & .171 & -4.739 & 0.007 & -8.406 & 0.000 \\
\hline CFFO & 3.396 & .014 & 0.602 & 0.783 & -2.996 & 0.397 \\
\hline CFFI & 3.640 & .109 & 2.500 & 0.023 & -1.620 & 0.751 \\
\hline CFFF & 0.651 & .781 & 4.811 & 0.001 & 3.261 & 0.490 \\
\hline NITA & -1.473 & .027 & -0.905 & 0.402 & -5.076 & 0.029 \\
\hline CINVTA & -2.492 & .158 & 6.815 & 0.018 & 0.452 & 0.919 \\
\hline \multicolumn{3}{|c|}{ Model -2 LOG L ${ }^{3}$} & \multicolumn{2}{|c|}{$36.768^{* *}$} & \multicolumn{2}{|c|}{$69.722 * * * *$} \\
\hline \multicolumn{7}{|c|}{ Change in -2 LOG L ${ }^{4}$} \\
\hline Panel B - P & \multicolumn{2}{|c|}{2.227} & \multicolumn{2}{|c|}{$6.921^{* *}$} & \multicolumn{2}{|c|}{0.010} \\
\hline \multicolumn{7}{|c|}{$\begin{array}{l}{ }^{1} \text { The models included the following variables: SIZE }=\log \text { of (total assets - inventory), OETL = (owners' } \\
\text { equity - inventory) divided by (total liabilities + inventory), CATA = (current assets - inventory) } \\
\text { divided by (total assets - inventory), CFFO = cash flow from operating activities divided by (total assets } \\
\text { - inventory), CFFI = cash flow from investing activities divided by (total liabilities + inventory), CFFF = } \\
\text { cash flow from financing activities divided by (total liabilities + inventory), NITA = net income divided } \\
\text { by (total assets - inventory), and CINVTA - (ending inventory - beginning inventory) divided by (total } \\
\text { assets - inventory). The response variable for each firm, FIRM = } 0 \text { if healthy, } 1 \text { if bankrupt or caused } \\
\text { loss to creditors ( } 76 \text { health and } 32 \text { distressed manufacturing firms). } \\
{ }^{2} \mathrm{P} \text {-value of the Wald chi-square statistic for each parameter estimate. } \\
{ }^{3} \text { The -2Log Likelihood Statistic follows a Chi-square distribution with seven degrees of freedom for the } \\
\text { reduced model and eight degrees of freedom for the full model. } \\
{ }^{4} \text { The Change in -2Log Likelihood Statistic follows a Chi-square distribution with one degree of freedom. }\end{array}$} \\
\hline \multicolumn{3}{|c|}{$\begin{array}{l}* \text { Significant at } \mathrm{p} \text {-value }<.05 \\
* * * \text { Significant at } \mathrm{p} \text {-value }<.001\end{array}$} & \multicolumn{4}{|c|}{$\begin{array}{l}* * \text { Significant at } \mathrm{p} \text {-value }<.01 \\
* * * * \text { Significant at } \mathrm{p} \text {-value }<.0001\end{array}$} \\
\hline
\end{tabular}


179) found that correlation among the explanatory variables' parameter estimates of 0.50 or higher can produce bias in Wald chi-square statistical tests. Such correlation can also cause imprecise parameter estimates.

Many parameter estimates were highly correlated. For example, all the cash flow variables' parameter estimates were highly correlated with each other in Year -1 in both the unadjusted and adjusted models. In Year - 2, in both models, the parameter estimates of the cash flow variables were highly correlated. In Year -3 the parameter estimates for CFFO and NITA were highly correlated in both models. Some other parameter estimates were also highly correlated in the models. Consequently, the parameter estimates on several variables may be imprecise and Wald chi-square tests may be biased.

Even if correlation among the parameter estimates causes imprecise parameter estimates on individual variables, the $-2 \log$ Likelihood statistics for the models are reliable and measure the overall explanatory power of the models. Also, the Change in the -2Log Likelihood statistic when one variable is added to a model provides an unbiased test of that variable's incremental explanatory power. The Change -2Log Likelihood Statistic follows a Chi-square distribution with one degree of freedom.

The Change in -2Log Likelihood statistics (from Panel A to Panel B) in both Tables 2 and 3 indicate that the change in inventory (CINVTA) adds significant explanatory power to the models in Year - 2 . These results are consistent with those reported in Table 2.

Comparing the -2 Log Likelihood statistics of the unadjusted models in Table 2 and the adjusted models in Table 3 reveals the impact of treating inventory as a liability on the models' explanatory power. Table 4 reports the models' -2 Log Likelihood statistics and the difference between those statistics. In Year -2 and Year 3 , the statistics for the adjusted models exceed those of the unadjusted models by from 5.886 to 11.837. However, in Year - 1 the statistics for the unadjusted models exceed those of the adjusted models by 4.041 and 4.297.

These differences in the $-2 \log$ Likelihood statistics are interesting because the only difference in the models is that inventory is treated as a liability in the adjusted models' variables -- otherwise the same variables and samples were used for each analysis. The increases in the $-2 \log$ Likelihood statistics indicate that the explanatory power of distress models for manufacturing firms improve three and two years prior to the event if inventory is treated as a liability. However, treating inventory as a liability reduced the models' overall explanatory power one year prior to distress.

We could not determine the significance of these differences in the -2Log Likelihood statistics because the models compared have the same degrees of freedom. However, as an example only, if changes in the unadjusted models' -2Log Likelihood statistics were caused by adding one variable to the models, the differences would have been significant at a p-value $<.05$ in each year prior to distress.

The univariate results indicate that the change in inventory differs significantly between distressed manufacturing companies and their matched healthy manufacturing companies two years before the distressed event. Logistic regression results also indicate that the change in inventory adds significant explanatory power to distress models two years prior to the distress event. However, logistic results provide conflicting evidence on whether or not inventory should be viewed as a liability in manufacturing firms.

\section{Conclusions}

The ascension of JIT and TOC as popular and successful management concepts and research findings once again raise questions about current accounting reporting standards. In the context of explaining financial distress, we found evidence that the change in inventory significantly helps explain the difference between 


\begin{tabular}{|lcc|}
\hline \multicolumn{4}{c|}{ TABLE 4 } \\
Comparison of Model -2 Log Likelihood Statistics \\
for Adjusted and Unadjusted Logistic Regression Models
\end{tabular}

healthy and distressed manufacturing companies. We also found mixed support for the extreme view of JIT and TOC proponents that inventory is a liability for manufacturing firms. Adjusting financial information to conform to this view improved the ability of logistic regression models to explain the health or financial distress of manufacturing firms two and three years prior to distress.

Case study evidence suggests that implementing TOC and related performance measures can enhance a company's profit generating ability (see Noreen et al. 1995, 61-135). However, our inability to construct ratios based on TOC performance measures for this study confirms the difficulty of obtaining desired information from current financial reports. To compute TOC financial performance measures recom- mended by Goldratt, financial statement users need more detail on inventories -- the amount of raw materials, labor, and fixed overhead included in work-in-process and finished goods inventory.

Our finding that inventory is useful in financial distress models raises the suggestion that perhaps better information on manufacturing companies' inventories might provide additional useful information to financial statement users. Aggregation of expenses and allocations in currently reported inventory amounts do not allow outside financial statement users to construct TOC financial performance measures. Consequently, current financial reporting denies potential lenders and investors access to measures that could help in assessing the potential for future cash flows and in comparing alternative invest- 
ment opportunities.

\section{Suggestions for Future Research}

The FASB embraced the concept that accounting standard setters should require information useful to financial statement users (FASB 1980, 22). Our study and case study results indicate that some JIT and TOC concepts are important to company performance. Therefore, the FASB should require companies to report more detailed inventory information. If researchers can obtain such information, testing the usefulness of TOC financial performance measures could prove a fruitful avenue for further research.

Also, an extension of our research would be to probe further into the reasons for our conflicting findings. Balakrishnan et al. (1996) examined the impact of just-in-time (JIT) inventory systems on the returns of healthy firms. They found that only some firms were able to retain the cost savings that accompanied JIT implementation. Firms with high customer concentration were forced to pass the savings on to their customers. Perhaps some similar factors impact the results of this study.

\section{Endnotes}

1. For example, US companies successfully implementing JIT production systems include Harley Davidson, Hewlett Packard, and Lincoln Electronics. Companies successfully implementing TOC cost management systems include Western Textile, Baxter, and Kent Moore Cabinets.

2. For a detailed discussion of binary logit regression, see Hosmer and Lemeshow (1989).

3. As reported in their Table 2, Ward and Foster (1996) included the first nine variables and a net-quick-assets flow variable scaled by total assets in their model. They calculated the net-quick-assets flow variable to approximate a flow advocated by Thomas (1974). We have included net income scaled by total assets, another variable examined by Ward and Foster (1996) and used frequently in other prior financial distress research.

\section{References}

1. Aziz, A., D. C. Emanuel, and G. H. Lawson, "Bankruptcy Prediction - An Investigation of Cash Flow Based Models," Journal of Management Studies (September), pp. 419-437,1988.

2. _ and G. H. Lawson, "Cash flow reporting and financial distress models: testing of hypotheses," Financial Management (Spring), PP. 55-63, 1989.

3. Bahnson, P. R., and J. W. Bartley, "The Sensitivity of Failure Prediction Models to Alternative Definitions of Failure," $A d$ vances in Accounting, Vol. 10, pp. 255278, 1992.

4. Balakrishnan, R., T. J. Linsmeier, and M. Venkatachalam, " Financial benefits from JIT adoption: Effects of customer concentration and cost structure," The Accounting Review, (April), pp. 183-205, 1996.

5. Beaver, W. H. , "Financial ratios as predictors of failure," Journal of Accounting

Research, Vol. 4 (Supplement), pp. 71-127, 1966.

6. Casey, C. J., and N. J. Bartczak, " Cash flow - It's not the bottom line," Harvard Business Review, Vol. 62 (July-August), pp. 61-66, 1984.

7. __ and _ _ _ "Using operating cash flow data to predict financial distress: Some extensions," Journal of Accounting Research, Vol. 23 (Spring), pp. 384-401, 1985.

8. Financial Accounting Standards Board, Qualitative Characteristics of Accounting Information: Statement of Financial Accounting Concepts No. 2, Financial Accounting Standards Board, New York, 1980.

9. Freeman, D. H., Applied Categorical Data Analysis, Marcel Dekker, Inc., New York, 1987.

10. Gentry, J. A., P. Newbold, and D. T. Whitford, "Funds Flow Components, Financial Ratios, and Bankruptcy," Journal 
of Business Finance and Accounting, Vol. 14 (Winter), pp. 595-606, 1987.

11. Goldratt, E. M. and J. Cox, The Goal, Second Revised Edition, North River Press, Inc., New York, 1992.

12. , E. M., Sifting Information Out of the Data Ocean: The Haystack Syndrome, North River Press, Inc., New York, 1990.

13. , E. M., It's Not Luck, North River Press, Inc., New York, 1994.

14. Horngren, C. T., G. Foster, and S. M. Datar, Cost Accounting: A Managerial Emphasis, 9th ed., Prentice Hall, Upper Saddle River, NJ, 1997.

15. Hosmer, D. W. and S. Lemeshow, Applied Logistic Regression, John

Wiley and Sons, New York, 1989.

16. Institute of Management Accountants, Cases in Management Accounting Practice, Volume 8, Institute of Management Accountants, Montvale, New Jersey, 1992.

17. Lau, A. H-L., " A five-state financial distress prediction model," Journal of Accounting Research, Vol. 25 (1), pp. 127-138, 1987.

18. Neill, J. D., T. F. Schaefer, P. R. Bahnson, and M. E. Bradbury, " The Usefulness of Cash Flow Data: A Review and Synthesis," Journal of Accounting Literature, Vol. 10, pp. 117-149, 1991.

19. Noreen, E., D. Smith, and J. T. Mackey, The Theory of Constraints and its Implications for Management Accounting, North River Press Publishing Corporation, Great Barrington, MA, 1995.

20. Ruhl, J. M., "An Introduction to the Theory of Constraints," Journal of Cost Management, Vol. 10 (2), pp. 43-48, 1996.

21. Stone, M., and J. Rasp, "Tradeoffs in the choice between logit and OLS for accounting choice studies," The Accounting Review, Vol. 66 (1), pp. 170-187, 1991.

22. Thomas, A. L., The allocation problem: part two. Studies in Accounting Research No. 9, American Accounting Association, Sarasota, FL, 1974.

23. Ward, T. J., " Is the scaling measure used for cash flows important in predicting financial distress?," Journal of Applied Bus- iness Research, (Fall), pp. 134-140, 1993.

24. , "An empirical study of the incremental predictive ability of Beaver's naive operating flow measure using four-state ordinal models of financial distress," Journal of Business Finance \& Accounting, Vol. 21:4 (June), pp. 547-561, 1994.

25. , and B. P. Foster, " An Empirical Analysis of Thomas's Financial Accounting Allocation Fallacy Theory in a Financial Distress Context," Accounting and Business Research , (Spring), pp. 137-152, 1996. 